\title{
Preface to the fourth edition
}

Some years ago I opened a talk on teaching literary theory with this statement: 'There are many ways of teaching literary theory. The problem is that none of them work. ${ }^{\text {' }}$ All teachers of literary theory have that feeling from time to time, and all we can do in response is try to think up better explanations and attach better examples to them. A new edition is another chance to fail better at teaching literary theory. It is nearly a quarter of a century since this book first appeared, and my own views on theory have, of course, shifted in that period. I am especially aware of an accelerated shift since the early 2000s. For much of this period I taught a session at the annual Literary Theory Day at Rewley House, Oxford, applying three or four theories to a different short literary text each year. My feelings about theorised readings of literary texts remind me now of watching the pre-millennial eclipse at Southsea in Hampshire with eightyear-old Tom in 1999. I kept thinking that theory often eclipses the text, just as the moon's shadow obscures the sun in an eclipse, so that the text loses its own voice and begins to voice theory. Thus, the text is proved by theory to be riddled with deconstructive cul-desacs (see Chapter 3), or an enactment of the Oedipus Complex (Chapter 5), or an embodiment of Althusserian repressive structures (Chapter 8 ). That's how it was, at least, when theory was at its zenith during the 1980s and 1990s. When the literary text met the cutting edge of theory, it got turned over by the blade, like a ploughed

1 'The “Good Science” Approach to Teaching Literary Theory', English Association Bulletin, 174 (autumn/winter 2003), pp. 1-3. 
field. The outcome of all these encounters was the same - it was an endless parade of triumphant theoretical mastery.

One of the literary texts I used to show how theory 'tackled textuality', as I called it, was a poem called 'To the Man After the Harrow', by the Irish poet Patrick Kavanagh (1904-67). In the final stanza, the poet urges the ploughman to drive on regardless, ignoring the wildlife which may be harmed by the blade of the plough:

Forget the worm's opinion too

Of hooves and pointed harrow-pins,

For you are driving your horses through

The mist where Genesis begins.

What I began to emphasise, in talking about theory, was not the macho 'cutting edge' of theory, but the soft-edged mist of uncertainty, which Kavanagh unforgettably calls 'The mist where Genesis begins'. Ideas begin in a mist, in a place where we cannot be sure what we are getting into. The mist is the moment of potential, when we have lost sight of our usual landmarks and the mind is in a receptive state - John Keats called it 'negative capability' - it is the good and fertile state of not quite knowing. So I began saying that when theory meets text, we are not looking for a confident re-shaping of the literary text with the blade of theory, but for a more tentative and patient groping about in the mist - an acceptance, in other words, of how uncertain the outcome usually is when theory meets text. I tried to encapsulate it in a soundbite, and what emerged was 'When the irresistible force of theory meets the immovable object of the text, something has to give.' Sometimes the sophistication of the theory exposes the limitations of the text, and sometimes the sophistication of the text exposes the limitations of the theory. This thought, which took me several years to formulate (to think, even), felt liberating and revolutionary, and after it, everything was different. For me this was where Theory 1.0 became Theory 2.0.

One characteristic of the world of Theory 2.0 is a keen awareness of the particularity of the individual literary text (see Chapter 15 on new aestheticism). The text doesn't have a 'grain', in the sense of lines that all run predictably in the same direction, lines that we have merely to push against with our newly acquired theories. On the contrary, texts often have energies that run in all sorts of 
directions, crossing and contradicting and arguing with themselves. All that messy, sticky particularity is what makes it literature. It's the same with theories: what makes them interesting is not their magisterial certainty and consistency, but their blind spots, the corners they cut, their blurry edges, and their constant, and often conflicting, reformulations. These are the attributes that make them worth spending time on - reading them, thinking about them, arguing about them, talking back to them, and trying to make them into a practice of some kind. By 'a practice' I mean a way of trying to make things better. What things? Well, the world we live in, the way we think about each other, the way we live both our collective and our individual lives. Increasingly, I value theories and approaches that have open intellectual borders, fewer over-adulated superstars, and ideas which do not have the effect of ironing literary texts into theory-compliant flatness. In this book, that is the kind of approach I recommend and speak for. I believe that theory asks the right questions (a huge achievement), and that, at its most useful, it wants to engage us, not in a conversion, but in a conversation.

Aberystwyth, March 2017 
Peter Barry - 9781526153524

Downloaded from manchesterhive.com at ๑4/26/2023 02:57: ๑9PM via free access 